\title{
Research on the Collaborative Cultivation Mode of Logistics Specialty Talents under the Background of "New Business"
}

\author{
Zhao Lei*1,a, Zhang Yanhua*2 \\ ${ }^{1}$ School of Tourism Management. Wuhan University of Business Wuhan, China \\ ${ }^{2}$ Wuhan Vocational College of Communications and Publishing Wuhan, China
}

\begin{abstract}
With the development of the Internet and E-Commerce, logistics has maintained a sustained and rapid development trend since the 1980s. Its industry scale and service capacity have been significantly improved. It has become a new economic growth point in China, and logistics has become a pillar industry in the development of the national economy. With the vigorous development of logistics industry, more logistics talents are needed, and universities are the cradle of training talents. The logistics personnel training is far behind the logistics market demand, and those practice is weak during the process of the logistics professional teaching with the theory. Therefore, if there is chance to make a breakthrough, must rely on practical teaching to strengthen logistics theory and practice combination, with the help of practice process to improve the students' practical ability, related handling problems and straining capacity, including effectively improvement the comprehensive ability of students, for achievement the effective docking of school education and enterprises. Production-University-Research Collaboration training is an important way to cultivate students' practical ability and innovation ability, and it is also a new highlight of application-oriented universities, colleges and universities, as a new way to cultivate talents. School-enterprise integration practice teaching is the way to cultivate innovative talents and the core goal of higher education teaching reform in the new era. The collaborative cultivation mode of logistics talents provides an implementation plan for improving students' practical ability, practical ability, problem-solving ability and strain ability, and also provides a specific realization path for logistics professionals, to provide comprehensive talents more in line with the needs of enterprises. Therefore, under the background of new business, it is necessary to strengthen the cooperation between logistics industry and enterprises, and strengthen the research mode of collaborative education of professional talents oriented by industry-university-research. On the one hand, it is conducive to the cultivation of applied talents in colleges and universities, and on the other hand, it lays a favorable foundation for our school to cultivate applied talents serving local areas.
\end{abstract}

\section{Introduction}

The new business is based on the development of the existing business, responding to the challenges brought by science, technology, society and economy in the Internet Era. Cross-border E-Commerce is the new growth energy, which is the electronation of international trade in the context of economic globalization. It matches the features of "consumption upgrading, interconnection, big data, cloud computing and Internet + " under the background of New Business.

As a talent training base, colleges and universities need to study the construction path of logistics management major under the new era, so as to better adapt to the needs. The Ministry of Education mentions "applicationoriented" for seven times in the Establishment of Institutions of Higher Education during the 13th Five-Year Plan Period. Its Opinions point out that "applicationoriented institutions of higher learning mainly engage in the cultivation of application-oriented talents at the undergraduate level and above to serve the economic and social development, and engage in the research of social development and the application of science and technology". A new round of industrial transformation and scientific and technological revolution is booming around the world, giving rise to a series of major industrial changes and disruptive in science and technology, and having a profound impact on the global economic landscape. The cultivation of regional competitiveness is the driving force of regional economic development in the era of knowledge economy, and regional scientific and technological innovation. Knowledge spillover are the sources of regional competitiveness growth.

Local applied university's mission is to solve the personnel training structure and quality, which is not adapt to the economic structure adjustment and industrial upgrading. Its priority mission is providing practical and innovative talents, taking the initiative to adapt to the economic development of our country in the New Normal, and active integrating development of industry transformation and upgrading and innovation drive, to 
provide talent support for the optimization and upgrading of the national and local industrial structure. However, for a long time, China's higher education has been one-sided in pursuing "large and comprehensive", focusing on the cultivation of academic talents and other development mistakes, resulting in prominent structural contradictions, the insufficient supply of applied talents and other problems. The shortage of high-quality applied talents has become the bottleneck restricting China's economic transformation and upgrading. In this context, it is urgent for local colleges and universities to train more applied talents to adapt to the new era.

\section{Purpose and significance of the study}

The talent training of traditional business subjects focuses more on the classroom, mainly taught by the teachers in the school according to the selected textbooks. Under the background of "New Business", the logistics major oriented to the new technology industry must carry out the practical learning of the integration of industry and education in the school stage, so as to enable students to practice the comprehensive and applied ability, to face the challenges under the new development of new technology. Industry and teaching are interlinked by School-Enterprise Cooperation, which is integrated into the education cycle, promoting the in-depth reform of teaching, improving the quality of talent training.

\subsection{Integrate New Business concepts into daily teaching}

In daily education teaching, it puts new business in the area of the modern education concept and advanced ideas, including but not limited to, set of disciplines, talent training mode reform, curriculum system construction, update teaching content, teaching methods and teaching, which means to improve and perfect the teaching management and so on. It is the deep connection of knowledge and technology, and a comprehensive blend of business, technology and humanities. On the basis of new changes in business models, the old ideas of talent training will be completely changed and new ideas will be formed. It could enrich the teaching content, improve the learning efficiency, and enhance the research ability.

\subsection{Develop a new mode of collaborative training for talent cultivation}

In the whole education and teaching reform system, the reform of talent training mode is considered to be the most core and key, which can provide programmatic guidance for the reform of other modules. It could reconstruct the talent training process, which is led by improving practical ability, establishing the talent training mechanism and mode of the integration of industry and education, and the cooperation between government, business and enterprises.

\subsection{Improve the tripartite coordination mechanism among enterprises, universities and educational service institutions}

In the joint implementation of teaching, teacher training, curriculum development, equipment investment, four aspects of in-depth cooperation and joint construction, it promotes the transformation and upgrading of schoolenterprise cooperation, from the basic ability of industrial and commercial integration and sharing platform construction to the professional ability of integration of theory and practice and professional platform construction, and finally step into regional economic service of new business practice education complex. It could establish a demonstration center for collaborative education and innovation, brew a socialized co-education system of university government and business cooperation and education, and create an education ecology of new business.

\subsection{Integrate new disciplines and improve professional education groups}

New business forms such as new retail, new finance, new management and new manufacturing, which are emerging one after another. New experiences give birth to new businesses, and new businesses give birth to new jobs, which require the cultivation of new business talents. Therefore, local colleges and universities must strengthen the specialty, reconstruct the specialty, and rebuild the specialty, so as to perfect the specialty and specialty group education of new business.

\subsection{Cultivate a team of double-qualified teachers s}

In the new business education of local application-oriented colleges and universities, in order to complete the tasks of integrating new technology, setting up new majors and teaching new courses, cultivate application-oriented, innovative and composite talents, a team of teachers with high teaching and research level is required. Professional technology and social service ability, and a group of double-qualified teaching backbone should be established.

\section{The Production-University-Research Cooperative Cultivation Mode for Logistics Professional Talents under the Background of "New Business"}

\subsection{Train logistics talents to meet social needs}

The training of business talents should not only meet the needs of the industry and serve the social business, but also meet the needs of social development and meet the major strategic needs of our country. Therefore, the training of modern logistics talents must highlight their social ability, including social communication ability, communication and expression ability, team cooperation ability and lifelong learning ability. At the same time, it should also 
be paid to training students to be honest in business and assume social responsibility. It should be placed on cultivating people with culture and virtue. For paying attention to students' professional ability, we should also pay more attention to their comprehensive quality and increase their humanistic quality.

\subsection{Make use of local advantages to establish teaching practice bases}

The key goal of local application-oriented colleges and universities is to train local new business talents and serve the needs of local economic and social development, because they are based on the region and radiate surrounding enterprises. At the same time, the local economic and social development have also provided a teaching practice base for the training of New Business talents, and created a natural condition for the integration of industry and education and the collaborative development.

Local colleges and universities should be familiar with their own regional business environment and industrial development status, so as to cultivate "marketable" local New Business talents. They should make good use of the advantages of local leading industries, emerging industries and characteristic industries, to enrich the teaching content of New Business education.

\subsection{Pay attention to the practical application of logistics personnel training}

Business is a scientific subject with both theory and practicality. It not only needs to learn theoretical knowledge, but also needs to guarantee the correctness of theory application and the accuracy of business problem handling, through a lot of teaching practice and field practice on this basis. It comes from social and economic practice and is applied in practice in turn, which determines the New Business education for the strong correlation between social and economic activities and practice guidance. The talented person must have a strong practical ability, in the work of general skills and professional logistics related core skills, using scientific theory and method of comprehensive analysis in practice, formulating and implementing the solutions to solve the problem, continuing to apply knowledge to practice, and modelling the comprehensive professional ability of the New Business talents.

\section{Conclusion}

In applied college teaching system, study in collaborative cultivating model plays an important role. This article is based on in the background of the New Business between fusion and collaborative education of production, studying and teaching mode reform, to meet the needs of society, from training logistics talents, the use of local advantages, to establish teaching practice bases. It pays attention to logistics personnel training and construction of teacher's team put forward opinions. It has certain reference significance to improve students' practical ability, innovative ability, comprehensive quality and problemsolving ability.

\section{Acknowledgment}

This paper is supported by Project of China Society of Logistics, Project Title: Exploration on the ProductionUniversity-Research Cooperative Cultivation Mode of Logistics Professional Talents under the Background of" New Business", Project No. 2021CSLKT3-306).

\section{References}

1. Wu Ting. Research on the Reform of Practical Teaching Mode of Logistics Management Major under the Background of "Mass Entrepreneurship and Innovation" -- Taking Guangzhou Institute of Technology as an Example [J]. Logistics Science and Technology, 2017(6):152-155.

2. Ding Yang. Research on the System Construction of Application-oriented Universities under the Background of "Mass Innovation and Innovation" -Taking the Practical Teaching of Logistics Management Major as an Example [J]. Education Economics, 2018(12):81-82.

3. $\mathrm{Bi} \mathrm{Na}$. Construction of "Double Wheel Drive" Practical Teaching Mode for Logistics Management Major from the Perspective of Innovation and Entrepreneurship -- Taking Baicheng Normal University as an Example [J]. Education Economics, 2019(3):87.

4. Qin Yi, Yan Rui. Research on the practical teaching reform of logistics major in local transformed undergraduate universities -- taking Yuncheng University as an example [J].Education Research, 2017,39(3):171-172.

5. Qi Chengming, Hu Lishuan, Sun Xue, et al. Exploration of logistics talents training mode based on practical teaching of supply chain curriculum system [J]. Logistics Technology, 2017(5):175-178.

6. Guo Donghui. Research on practical teaching of logistics management major based on employment [J]. Science and Technology Innovation Herald, 2018(27):200-201. 